\title{
Cost-efficient Nearly Zero-Energy Buildings
}

\author{
Heike Erhorn-Kluttig ${ }^{1, *}$, Hans Erhorn ${ }^{1}$, and Micha Illner $^{1}$ \\ ${ }^{1}$ Fraunhofer Institute for Building Physics, Department Energy Efficiency and Indoor Climate, Nobelstr. 12, 70569 Stuttgart, \\ Germany
}

\begin{abstract}
The next level of energy performance of new buildings within the European Union will be the Nearly Zero-Energy Building (NZEB). A lot of work has been spent on pilot and demonstration buildings on this and also even higher energy performance levels throughout all EU countries. However, most of the high performance buildings realised so far result in higher investment costs when compared to the current national minimum energy performance requirements. The considerably higher investment costs are one of the main barriers to the early application of the NZEB-level in Europe. The EU H2020 project CoNZEBs works on technical solution sets that result in lower investment costs for NZEBs, bringing the costs close to those of conventional new buildings. The focus is on multi-family houses. In each of the four participating countries Germany, Denmark, Italy and Slovenia a team of researchers is analysing which sets of marketready technologies at the building envelope, the services systems for heating, domestic hot water, ventilation and cooling (where required) in combination with renewable energy systems can fulfil the NZEB requirements at lower costs than those incurred by the national mainstream NZEB application. Additional efforts are being spent on the life-cycle costs and the life-cycle analysis of the solution sets, as well as on the impact of future developments of primary energy factors, energy costs and technology efficiencies.
\end{abstract}

\section{Introduction}

The next level of energy performance of new buildings within the European Union will be the Nearly ZeroEnergy Building (NZEB). The EU Member States are obliged to define the minimum energy performance requirements for the NZEB building level that will be in force for new public buildings from 2019 and for all new buildings from 2021 according to the Energy Performance of Buildings Directive (EPBD), [1]. A lot of work has been spent on pilot and demonstration buildings on this and also even higher energy performance levels throughout all EU countries as reported for example by the Concerted Action EPBD [2], an EU country platform to support the implementation of the EPBD [3], [4]. The development of energy concepts for high performance buildings up to plus energy buildings is also one of the key research areas of the Fraunhofer Institute for Building Physics.

However, most of the high performance buildings result in higher investment costs when compared to the current national minimum energy performance requirements. Concerted Action has published a report [3] in which the average of the additional investment costs was determined to be $11 \%$ of the total building costs or slightly above $200 € / \mathrm{m}^{2}$ based on 32 international built examples. The considerably higher investment costs are one of the main barriers to the early application of the NZEB-level in Europe.

The EU H2020 project CoNZEBs [5] (Solution sets for the Cost reduction of new Nearly Zero-Energy
Buildings) works on technical solution sets that result in lower investment costs for NZEBs bringing the costs close to those of conventional new buildings. The focus is on multi-family houses. In each of the four participating countries Germany, Denmark, Italy and Slovenia a team of researchers is analysing which sets of marketready technologies at the building envelope, the services systems for heating, domestic hot water (DHW), ventilation and cooling (where required) in combination with renewable energy systems can fulfil the NZEB requirements with lower costs than those of the national mainstream NZEB application. The identified solution sets and their included technologies are described in detail as result of the work. It is also analysed whether a solution set is transferable to other EU countries. All these calculations are based on four typical national multi-family houses taking into account the different building cultures of the four countries. Additional efforts are being spent on the life-cycle costs (LCC) and the life-cycle analyses (LCA) of the solution sets as well as on the impact of future developments of primary energy factors, energy costs and technology efficiencies. CoNZEBs works together closely with stakeholders such as housing organisations and housing associations which will pave the way for realising the cost-efficient solution sets in practice. National advisory boards consisting of ministry officials and staff members of subordinate authorities or energy agencies give feedback about the work in general and especially on the practicability of the solution sets with regard to the legal frameworks.

* Corresponding author: heike.erhorn-kluttig@ibp.fraunhofer.de 


\section{Setting the baseline: Investment costs for three different energy performance levels}

In order to identify the currently existing investment cost gap for multi-family houses each national team has collected investment costs of buildings realised on three different energy performance levels:

- Minimum energy performance requirements

- Nearly zero-energy buildings (NZEBs)

- $\quad$ Beyond NZEBs

The collected cost data includes the total building costs, costs for the building components and services systems costs and annual energy costs where available. Figure 1 presents the identified investment costs for building components and services systems of 46 German multi-family houses related to the specific living area. The national case studies present either buildings of the housing organisations involved in the project, demonstration buildings of the included research partners or data from internet research or other publications.

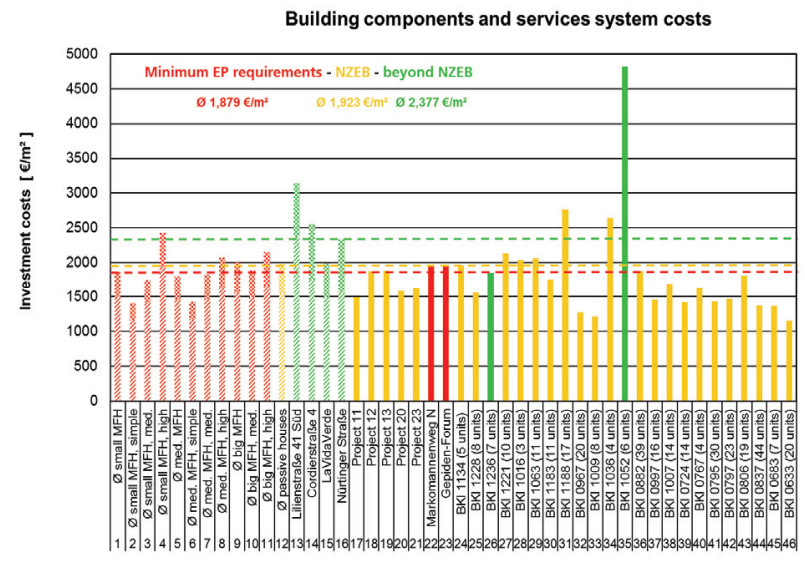

Fig. 1. Investment costs for building components and services systems of German multi-family houses on three different energy performance levels.

Based on a total of 79 case studies, national average cost gaps between multi-family houses fulfilling the minimum energy performance requirements and nearly zero-energy buildings have been identified as presented in Table 1. It has to be noted, though, that in some countries it was difficult to find a statistically significant number of cases for representing all three energy performance levels. Based on the available data, the determined average investment-cost differences between NZEBs and buildings fulfilling the current minimum energy performance requirements range between $44 € / \mathrm{m}^{2}$ living area in Germany and $229 € / \mathrm{m}^{2}$ useful area in Italy [6].
Table 1. Average investment cost difference for building components and building services systems between NZEBs and buildings built according to the minimum energy performance requirements in Germany, Denmark, Italy and Slovenia.

\begin{tabular}{|c|c|}
\hline Country & $\begin{array}{c}\text { Difference of the average investment costs for } \\
\text { building components and building services } \\
\text { systems of the NZEB and the minimum } \\
\text { energy performance building level }\end{array}$ \\
\hline Germany & $44 € / \mathrm{m}^{2}$ living area \\
\hline Denmark & $65 € / \mathrm{m}^{2}$ gross floor area \\
\hline Italy & $229 € / \mathrm{m}^{2}$ useful area \\
\hline Slovenia & $104 € / \mathrm{m}^{2}$ conditioned net floor area \\
\hline
\end{tabular}

with:

- $\quad$ Living area: Floor area defined in [7] as living area ("Wohnfläche") and used as the basis for calculating the rent of dwellings. It basically comprises the net floor area of all rooms, but employs a reduction factor for room parts with low heights; besides, it adds the areas of balconies (also multiplied with a reduction factor).

- Gross floor area: Total floor area of the building including the external walls.

- Useful area: Italian "superficie utile" as defined in [8]. The area is equal to the net floor area, thus being the gross floor area minus the construction area (external and internal walls).

- Conditioned net floor area: Here only the net floor area of the rooms that are conditioned (heated or cooled) is taken into account.

\section{Cost savings at the design and con- struction processes}

Literature research and a questionnaire for designers and construction companies gave insight into the average cost distribution of newly built residential buildings. For Germany the allocation of the median building cost value according to [9] is presented in Fig. 2.

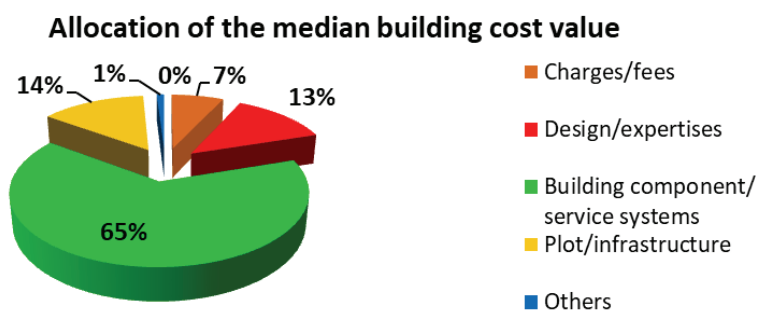

Fig. 2. Allocation of the median building cost value for new German residential buildings in fast-growing regions and metropolitan areas [9]. 
In the participating countries the following average design costs have been identified [10]:

- Germany $13 \%$ of the total building costs (median costs)

- Denmark $8-15 \%$ of the total construction costs

- Italy $8 \%$ (7\% for minimum requirement buildings and $9 \%$ for NZEBs)

- $\quad$ Slovenia $4 \%$

The project also investigated how cost savings can be achieved in the design and construction processes. Studies were either conducted within the project or collected by literature research. The following measures at the building envelope and the service systems seem to be promising, especially in the countries indicated:

- Large autoclaved concrete blocks (Italy): 48\% time saving for building the external walls

- Mono-block windows (Italy): 20\% cost saving, $60 \%$ time saving

- Roof-integrated photovoltaic (Denmark): 28\% cost savings if compared to a conventional roof with added PV

- Hygro-sensitive ventilation (Slovenia): reduced ventilation rate leads to less heating energy demand and thus can compensate for slightly less insulation

- Passive cooling through solar shading, roof overhangs and trees (Italy): No mechanical cooling required

- Cross-laminated timber panels instead of conventional walls (Slovenia): higher investment costs but significantly shorter construction time

- Air-heating with heat taken from the domestic hot water circulation (Denmark): $40 \%$ time and cost savings

- Unheated external staircases (Germany): reduction of the surface-to-volume ratio leads to lower heating energy use and lower costs due to a reduced façade area. A multi-family house in Stuttgart Stammheim has been built based on a revised design, see Figure 3 and Figure 4. As a rule of thumb: A reduction of the surface-to-volume ratio by $0.1 \mathrm{~m}^{-1}$ results in decreasing the heating energy demand by up to $10 \mathrm{kWh} / \mathrm{m}^{2} \mathrm{yr}$ while saving building costs of 50 to $80 € / \mathrm{m}^{2}$ under current German boundary conditions.
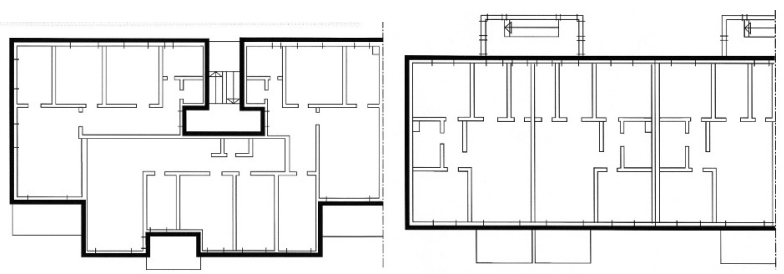

Fig. 3. Drawings of half of the floor plan of the multi-family house in Stuttgart-Stammheim according to first and second design [11].

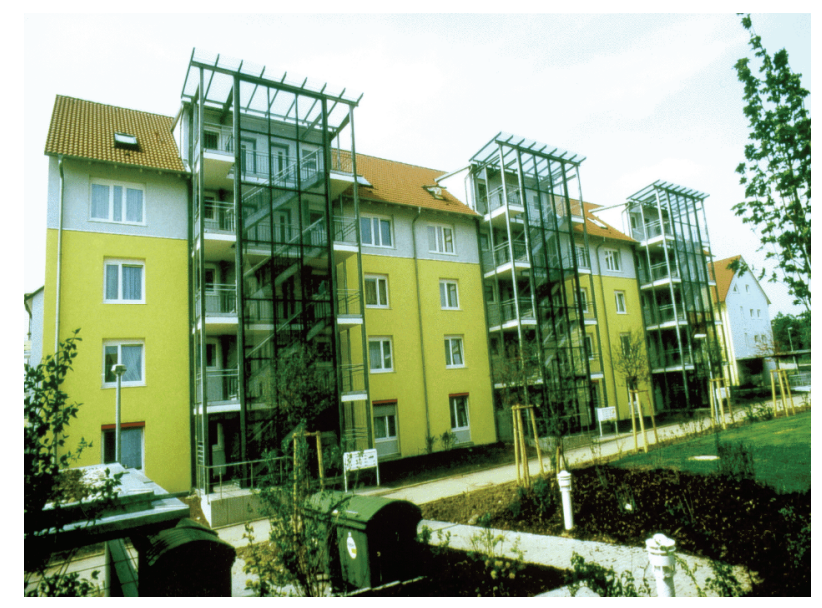

Fig. 4. Photos of the multi-family house in Stuttgart-Stammheim realised with external staircases.

CoNZEBs also studied possible cost savings due to different planning and construction processes. In many countries, experts rate the use of pre-fabricated building components as cost-saving in the future. The project could however not find any quantitative results of corresponding studies. The use of Building Information Modelling (BIM) is also creating high hopes for various advantages, as shown in Figure 5 [12]. 1,600 architects have been interviewed regarding their expectance concerning BIM.

\section{European architects: Top advantages of BIM (trend cluster; $n=1,600$ )}

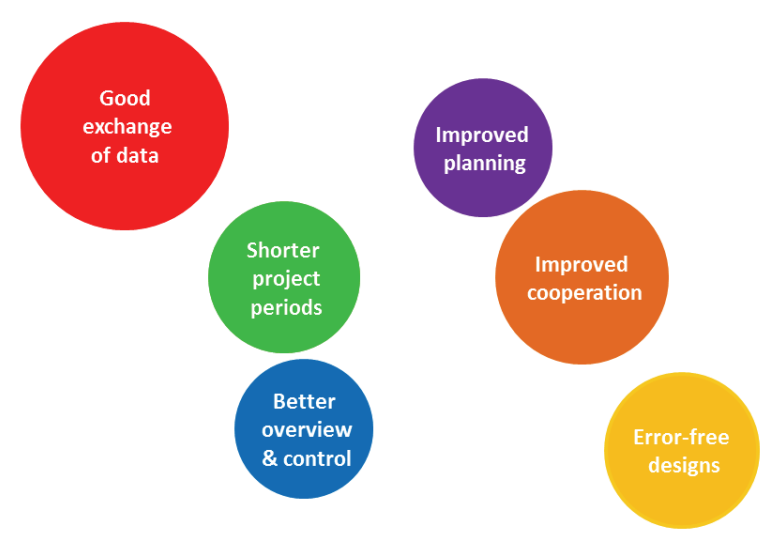

Fig. 5. Highest rated benefits of using BIM according to a survey conducted among 1,600 European architects [12].

On the other hand, only few studies could be found that present quantitative data on potential cost-savings. First experiences have been made in the USA [13], UK [14] and Hong Kong [15] showing average cost savings of $1.9 \% / 3 \%$ and $7 \%$.

\section{Cost savings due to alternative ener- gy concepts}

The CoNZEBs partners have conducted detailed studies comparing the conventional national way of building 
NZEBs with alternative energy concepts that can save investment costs. For this purpose, three steps have been performed in the 4 participant countries:

1. Definition of a typical national multi-family house

2. Definition of the typical national NZEB solution as base case

3. Identifying alternative energy concepts fulfilling the NZEB requirements with lower investment costs

Fig. 6 shows the four typical multi-family houses used for the studies [16]. The typical NZEB solutions differ between the countries. While for example the German and Slovenian typical NZEB solutions contain a central heating system based on a gas condensing boiler in combination with solar thermal collectors, the Danish concept is based on district heating while the Italian concept features an air-to-water heat pump. The other components of the energy concept, e.g. the ventilation system, the domestic hot water generation and the thermal quality of the building envelope, are countrydependent, as well, see also chapter 4.2. The national standard calculation methods for determining the energy performance of buildings have been chosen as calculation methods. The investment costs and energy tariffs are based on national cost databases and the experience of the national teams.

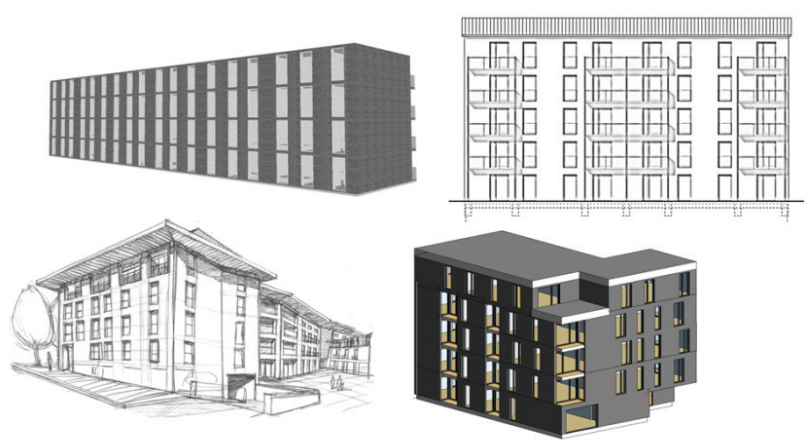

Fig. 6. Views of the four typical national multi-family houses used by the CoNZEBs partners to identify alternative NZEB energy concepts resulting in lower investment costs. From top left in clockwise direction: Danish, German, Italian and Slovenian typical building.

\subsection{German base case and alternative solution sets}

In the following section the results of the German study on investment cost-saving NZEB solutions are summarised. The base case, e.g. the typical German NZEB energy concept, presented in Fig. 7, was defined as:

- High insulation level of the building envelope $\left(\mathrm{H}^{\prime}{ }_{\mathrm{T}}=0.22 \mathrm{~W} / \mathrm{m}^{2} \mathrm{~K}\right)$

- Gas condensing boiler plus solar thermal collector as central heating and DHW system

- Mechanical exhaust ventilation system

At the start of the CoNZEBs project, the detailed German application of the NZEB definition within the EPBD [1] had not yet been fixed in a legal document. This is why, the German team had to define a CoNZEBs NZEB level. In accordance with [17] they chose the KfW efficiency house 55-level, with a non-renewable primary energy demand that is $55 \%$ lower than the reference building specified in the German energy ordinance [18] and $26 \%$ lower than the current minimum energy performance requirements for new buildings. As an additional requirement, the transmission heat transfer coefficient $\mathrm{H}^{\prime}{ }_{\mathrm{T}}$ (equivalent to an average $\mathrm{U}$-value of the whole building envelope) has to be $30 \%$ lower than the reference building.

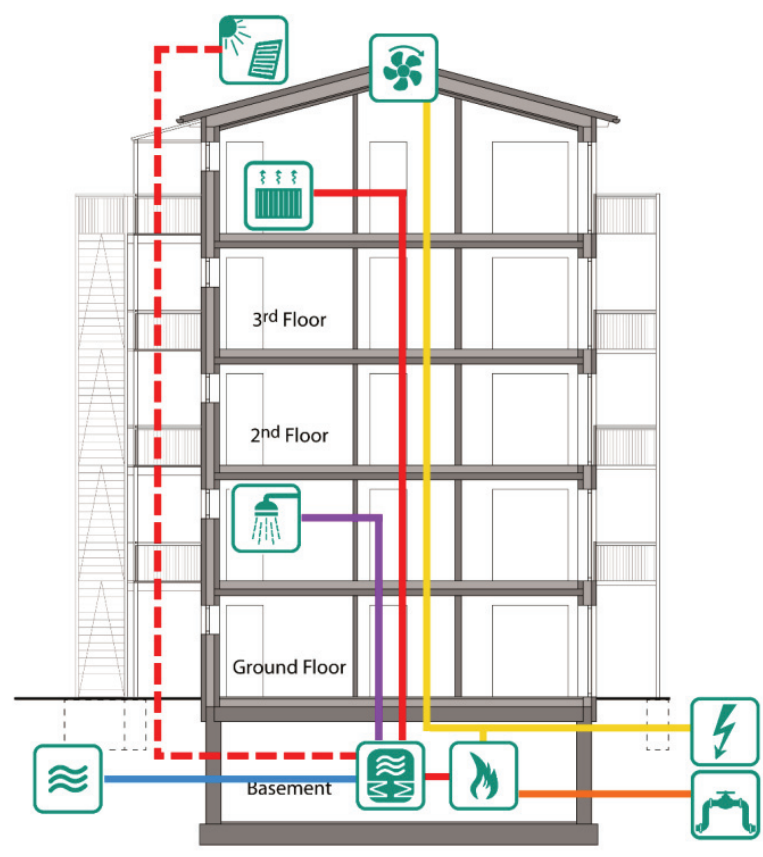

Fig. 7. Energy concept of the German typical NZEB as base case for the German alternative solution sets.

Compared to this base case, the German team has identified four energy concepts that result in lower calculated investment costs.

1. Decentral electrical space heating and DHW system, decentral ventilation system with heat recovery, roof $\mathrm{PV}$, heat recovery from shower waste water and reduced insulation level.

2. Central supply and exhaust ventilation and air heating system with an exhaust air-to-air heat pump, decentral electrical DHW heater, heat recovery from shower waste water and reduced insulation level.

3. Central combined space heating and DHW system with district heating, central exhaust ventilation system and reduced insulation level.

4. Central space heating system with exhaust air-towater heat pump (in central exhaust ventilation system) supported by a gas condensing boiler, decentral DHW heat exchange modules, roof PV panels and reduced insulation level.

Table 2 presents the calculated energy and cost results for the German NZEB base case and the four alternative energy concepts. 
Table 2. Results of the calculated energy and cost comparison between the German NZEB base case and the alternative

NZEB energy concepts. The energy data and cost data are related to the net floor area of the building.

\begin{tabular}{|c|c|c|c|c|c|}
\hline \multirow{2}{*}{ Energy concept } & \multirow{2}{*}{$\begin{array}{l}\text { Base } \\
\text { case }\end{array}$} & \multicolumn{4}{|c|}{ Alternative solution sets } \\
\hline & & 1 & 2 & 3 & 4 \\
\hline $\begin{array}{c}\text { Building } \\
\text { envelope } \\
\text { quality: } \\
\text { Transmission } \\
\text { heat transfer } \\
\text { coefficient } \mathbf{H}^{\prime} \text { ' } \\
{\left[\mathrm{W} / \mathbf{m}^{2} \mathbf{K}\right]} \\
\end{array}$ & 0.22 & 0.31 & 0.31 & 0.31 & 0.31 \\
\hline $\begin{array}{c}\text { Non-renewable } \\
\text { primary energy } \\
{\left[\mathrm{kWh} / \mathrm{m}^{2} \mathrm{yr}\right]}\end{array}$ & 48.85 & 41.09 & 48.60 & 48.39 & 47.60 \\
\hline $\begin{array}{c}\text { Difference of } \\
\text { the investment } \\
\text { costs to the base } \\
\text { case }\left[€ / \mathbf{m}^{2}\right]\end{array}$ & 0 & -84 & -57 & -83 & -44 \\
\hline $\begin{array}{c}\text { Energy costs } \\
{\left[€ / \mathbf{m}^{2} \mathbf{y r}\right]}\end{array}$ & 3.33 & 6.43 & 6.91 & 7.00 & 4.22 \\
\hline
\end{tabular}

Investment cost savings are derived from either alternative service system components (including partly omitted distribution systems) and from reduced insulation levels (in all four cases). In the case of energy concept \#2 the potential reduction in the thermal building envelope quality could not be completely exploited due to the secondary energy performance requirement, the maximum transmission heat transfer coefficient.

Table 2 shows that all four alternative energy concepts result in lower investment costs. If the investment costs are however compared to the annual energy costs, the attractiveness of the base case (using gas as the main energy source) becomes clear. Only energy concept \#4 produces similarly low annual energy costs, which is why it will be a more cost-efficient solution even after more than 30 years, if compared to the base case in a non-dynamic way.

\subsection{Other national base cases and alternative solution sets}

Dependent on the building culture and the national detailed definition of the nearly zero-energy building level the other three country teams have determined their typical NZEB solution set (national base case) as follows:

- Denmark: Average U-value of the building envelope of $0.26 \mathrm{~W} / \mathrm{m}^{2} \mathrm{~K}$; space heating (and DHW) generated by district heating and emitted by radiators; balanced mechanical ventilation with $90 \%$ heat recovery.

- Italy: Average U-value of the building envelope of $0.34 \mathrm{~W} / \mathrm{m}^{2} \mathrm{~K}$ (base case Rome) or $0.30 \mathrm{~W} / \mathrm{m}^{2} \mathrm{~K}$ (base case Turin); space heating generated by an air-towater heat pump, a gas boiler and PV panels and emitted by radiators; DHW generated by the gas boiler and supported by solar thermal collectors; natural ventilation by opening of windows.

- Slovenia: Average U-value of the building envelope of $0.41 \mathrm{~W} / \mathrm{m}^{2} \mathrm{~K}$; space heating (and DHW) generated by a gas condensing boiler supported by thermal solar collectors and emitted by floor heating; decentral mechanical ventilation.

The identified and assessed alternative solution sets include:

- For Denmark:

- More efficient insulation material in the external walls (phenolic insulation boards, $\lambda=$ $0.02 \mathrm{~W} / \mathrm{mK}$ )

- DHW solar heating and reduced insulation in the external walls

- 4-layer glazed windows, natural ventilation and heat recovery of grey wastewater

- Decentral mechanical ventilation, PV panels and reduced insulation at the opaque building envelope

- For Italy:

- Large autoclaved concrete bricks resulting in the same thermal transmittance of the wall as in the base case, but reduced construction time and costs

- Mono-block widows including roller shutter boxes resulting in the same U-value as in the base case, but reduced construction time and costs

- Condensing boiler with solar thermal support for both, heating and DHW

- Air-to-water heat pump for both, heating and DHW

- Direct electrical heating with most of the electricity generated by PV panels

- For Slovenia:

- District heating system for space heating and DHW generation and decentral mechanical ventilation with $85 \%$ heat recovery

○ Air-to-water heat pump for space heating and DHW, triple glazed windows, decentral mechanical ventilation with $85 \%$ heat recovery

- Air-to-water heat pump for DHW, gas condensing boiler for heating, triple glazed windows, decentral mechanical ventilation with $85 \%$ heat recovery

- Air-to-water heat pump for DHW, gas condensing boiler for heating, triple glazed windows, hygro-sensitive mechanical ventilation plus PV

It has to be mentioned that a few of the solution sets are not meeting the national building regulations (e.g. natural ventilation in case of Denmark, direct electrical heating in case of Italy). Nearly all listed solution sets result in lower investment costs if compared to the national base case (typical NZEB solution). This is however not the case for the second and third Danish solution set which result in marginally higher investment costs. The annual energy costs are either lower or higher than the base case, depending on the changes 
implemented and the national energy tariffs. Further details can be found in [15].

\subsection{Main conclusions of the technical solution set study}

The results of the investment-cost comparison between the national base case (typical NZEB solution) and the alternative solution sets are strongly dependent on the typical NZEB solution that was selected as base case. Here two countries have used a similar base case (Germany and Slovenia with solar supported gas condensing boilers), while Denmark went for district heating and Italy for an air-to-water heat pump in combination with a gas condensing boiler. The chosen technical building systems, but also the level of building insulation and type of window applied are mainstream solutions in the respective countries. This is the case because their investment costs (together with their maintenance costs and the resulting energy costs) are convincing arguments. Usually, a high market penetration also results in lower investment costs. This made the identification of alternative solution sets that result in lower investment-costs not an easy task. Nevertheless, the project team was able to identify in total 20 solution sets (at least 3 per country and climate) that meet the goal of achieving lower investment costs.

Lower investment costs have been the main goal of the work documented in chapter 4 . The other side of the story are the annual energy costs - or in order to be more comprehensive - the operating costs including the energy costs, but also the maintenance and replacement costs as studied in another subtask of the project (see chapter 5). Regarding the annual energy costs, the results are more diverse. At the first glance some of them may even appear contradictory among the countries involved. For example, the change from gas-driven systems to (more) electrical driven systems produces the following results:

- Germany: higher annual energy costs

- Italy: lower annual energy costs (in connection with electrical heat pumps) and higher annual energy costs in the case of the direct electrical heating

- Slovenia: lower annual energy costs

Certainly, this outcome is depending on the resulting energy use per solution set and the gas and electricity tariffs prevailing in the various countries, but it is also related to the combination of the system components selected - perhaps, even the different national calculation methods may have an influence.

Simple solutions, which only consider one change (such as a different insulation material or a different wall construction) are the easiest ones to assess. If they result in lower investment costs - while maintaining or even increasing the energy quality (lowering the U-value) they will not be counter-balanced by the annual energy costs.

The national teams have assessed whether solution sets from one country are interesting for the other three countries. Again, the different starting points (base cases), energy tariffs, typical buildings, climates, etc. have an impact on this assessment. With regard to low investment-costs, the Danish team considers the direct electrical resistance heating used in a few German and Italian solution sets as being interesting in their country as well. Due to the rather low primary energy factor of the district heating in their base case, the cost savings would have to be balanced with additional investments in the energy quality of the building envelope, though.

The German team sees a promising solution in the water saving fixtures. However the current German energy ordinance does not yet refer to the updated calculation standard DIN V 18599 which allows the reduction of the DHW flow based on the type of the fixtures. Additionally, this type of fixtures is associated with slightly lower comfort. Additional roof-top mounted PV (more than in already included in two German solution sets) could also be financially attractive, but the upcoming energy ordinance will probably prohibit balancing direct electrical heating with PV generated electricity. Other solution set components like hygro-sensitive (demand-controlled) ventilation and direct electrical heating are already part of German solution sets.

The transfer of solutions to Italy is regarded as complicated since both, the climate and - related to it also the market for high performance insulation materials are quite different. Besides the solution set using direct electrical heating, another common solution shared with other countries could be the use of district heating for generating the energy required for space and DHW heating.

The Slovenian team regards the balancing of a slightly lower building envelope level with solar thermal energy (as proposed in a Danish solution set) as an interesting approach. Further, the autoclaved aerated concrete blocks and the heat pump solutions in combination with PV might be effective in Slovenia, as well.

\section{Next steps}

The CoNZEBS partners are currently working on the life-cycle cost and life-cycle assessment of the different solution sets. Another focus will be on the evolving parameters for the calculation, such as the energy tariffs, primary energy factors, technology efficiencies and costs, etc. All results will be presented and discussed during national events involving the main stakeholders of the multi-family housing sector in 2019.

The CoNZEBs project has received funding from the European Union's Horizon 2020 research and innovation programme under grant agreement no. 754046. The paper reflects the authors' views. The Commission is not responsible for any use that may be made of the information it contains.

In Germany, national co-funding is provided by Bundesministerium für Umwelt, Naturschutz, Bau und Reaktorsicherheit within the research initiative Zukunft Bau (SWD10.08.18.7-17.33).

\section{References}

1. European Parliament and Council. Directive 2010/31/EU on the energy performance of buildings 
(recast), (2010) https://eur-lex.europa.eu/legalcontent/DE/TXT/?uri=celex\%3A32010L0031

2. Concerted Action Energy Performance of Buildings. Website of the EU country platform to support the implementation of the EPBD. www.epbd-ca.eu

3. H. Erhorn, H. Erhorn-Kluttig. Selected Examples of Nearly Zero-Energy Buildings. Detailed report of the Concerted Action Energy Performance of Buildings, (2014), www.epbd-ca.eu/wpcontent/uploads/2011/05/CT5 Report Selected exa mples of NZEBs-final.pdf

4. H. Erhorn, H. Erhorn-Kluttig. NZEB-like Educational Buildings. Pilot projects from 13 countries. Factsheet of the Concerted Action Energy Performance of Buildings, (2017). https://www.epbdca.eu/wp-content/uploads/2018/04/01CT1_Factsheet_NZEB Educational_Buildings.pdf

5. CoNZEBs. Solution sets for the cost reduction of new Nearly Zero-Energy Buildings. Website of the EU Horizon 2020 project CoNZEBs, (2017). www.conzebs.eu.

6. H. Erhorn-Kluttig et al. Overview of cost baselines for three building levels. Report of the EU Horizon 2020 project CoNZEBs, (2017).

www.conzebs.eu/images/CoNZEBS_D2.1 Overvie w_of_cost baselines_final2.pdf

7. Bundesgesetzblatt. Verordnung zur Berechnung der Wohnfläche, über die Aufstellung von Betriebskosten und zur Änderuing anderer Verordnungen, (2003).

https://www.bgbl.de/xaver/bgbl/start.xav?startbk=B undesanzeiger BGBl\&jumpTo=bgbl103s2346.pdf

8. Gazzetta Ufficiale della Repubblica Italiana. Intesa, ai sensi dell'articolo 8, comma 6, della legge 5 giugno 2003, n. 131, tra il Governo, le Regioni e $i$ Comuni concernente l'adozione del regolamento edilizio-tipo di cui all'articolo 4, comma 1-sexies del decreto del Presidente della Repubblica 6 giugno 2001, n. 380, (2001).

https://www.gazzettaufficiale.it/eli/id/2016/11/16/16 A08003/sg

9. D. Walberg et al. Kostentreiber für den Wohnungsbau - Untersuchung und Betrachtung der wichtigsten Einflussfaktoren auf die Gestehungskosten und auf die aktuelle Kostenentwicklung von Wohnraum in Deutschland, (2015).

www.bmu.de/fileadmin/Daten_BMU/Download_PD

F/Wohnungswirtschaft/buendnis baukostensenkung skommission bf.pdf

10. M. Zinzi et al. Assessment and exemplary solutions for cost reduction in the design and construction process. Report of the EU Horizon 2020 project CoNZEBs, (2018).

www.conzebs.eu/images/WP3 D3.1 Design and c onstruction process final2.pdf

11. H. Erhorn, H. Kluttig, J. Reiß. Kosten- und flächensparendes Konzept für ein Mehrfamilien-Niedrigenergiewohnhaus im sozialen Wohnungsbau. IBPMitteilung 312, (1997). https://www.ibp.fraunhofer.de/content/dam/ibp/de/d ocuments/Publikationen/IBPMitteilungen-optimiert/ $\underline{\text { 312.pdf }}$

12. USP/BauInfoConsult. Arch-Vision - European Architectural Barometer. Index \&Trends Q4, (2017). https://www.usp-mc.nl/en/insights/uspshop/shop/european-architectural-barometer/

13. S. Azhar, M. Hein, B. Sketo. Building information modeling (BIM): benefits, risks and challenges, 44th ASC Annual Conference Auburn, Alabama, edited, 2-5. (2008).

14. PwC. BIM Level 2 Benefits Measurement Methodology to Public Sector Capital Assets, (2018). www.cdbb.cam.ac.uk/Downloads/Level2/4.PwCBM MApplicationReport.pdf

15. W. Lu, A. Fung, Y. Peng, C. Liang, S. Rowlinson. Cost-benefit analysis of Building Information Modeling implementation in building projects through demystification of time-effort distribution curves. Building and Environment. 82. 317-327. 10.1016/j.buildenv.2014.08.030, (2014).

16. K. B. Wittchen et al. Solution sets and technologies for NZEBs. Report of the EU Horizon 2020 project CoNZEBs, (2019). www.conzebs.eu

17. Concerted Action Energy Performance of Buildings. Implementing the Energy Performance of Buildings Directive featuring Country Reports. Implementing the EPBD in Germany, (2016). www.epbd-ca.eu

18. Deutsche Bundesregierung. Verordnung über einen energiesparenden Wärmeschutz und energiesparende Anlagentechnik bei Gebäuden (Energieeinsparverordnung - EnEV), (2013).

http://www.bmub.bund.de/fileadmin/Daten BMU/D ownload PDF/Energieeffizient Bauen/energiesparv erordnung_lesefassung bf.pdf 